\title{
The Effectiveness of a Self-Questioning Strategy at Developing Academic Achievement and Critical-Thinking Skills among Secondary-School Students in Saudi Arabia
}

\author{
Ali Tared Aldossari* \\ Imam Abdulrahman Bin Faisal University, College of Education, \\ Curriculum \& Instruction Department, Dammam, Saudi Arabia \\ https:// orcid.org/0000-0001-6329-2387 \\ Mohammed Msnhat Aldajani \\ Imam Abdulrahman Bin Faisal University, College of Education, \\ Curriculum \& Instruction Department, Dammam, Saudi Arabia \\ https://orcid.org/0000-0002-8531-437X
}

\begin{abstract}
This study aims to examine how effective a self-questioning strategy is at developing academic achievement and critical-thinking skills in the jurisprudence curriculum (Fiqh), followed by secondaryschool students. The research sample is taken from secondary-school students in Dammam, the Kingdom of Saudi Arabia (KSA); 64 students from two different schools were selected: 32 as a control and 32 as an experimental group. The research instruments consist of an achievement test, a test to see how critical-thinking skills are applied to the Fiqh curriculum, and a teachers' guide to teaching the Fiqh curriculum, using the self-questioning strategy. The study recommends the use of the selfquestioning strategy when teaching the Fiqh curriculum to secondaryschool students. It also highlights the need to raise teachers' awareness of the importance of teaching critical-thinking skills. Considering the research results and recommendations, the researchers recommend several further avenues of research related to the current research variables.
\end{abstract}

Keywords: academic achievement; critical-thinking skills; Fiqh curriculum; self-questioning strategy; secondary-school students

\section{Introduction}

Islamic studies are a central subject at all academic levels in the Kingdom of Saudi Arabia (KSA); the curriculum guidelines state that "religious sciences are the basis

*Corresponding Author: Ali Tared Aldossari; Email: ataldossari@iau.edu.sa 
of all levels of study - primary, intermediate and secondary - and Islamic culture is the basis of all years of higher education" (Education Document, 1970). Modern methods of teaching are applied to such Islamic subjects. Abanmi (2016) states that traditional teaching strategies (such as lectures and indoctrination) are no longer accepted because they limit learner activity, passively impacting students' cognitive achievement, limiting their skills gains, and weakening their attitudes. As such, it is now advised that teaching strategies should be reconsidered. AlMofda (2005) stresses this needs, while Abu Ajwa (2009) highlights the importance of interaction between teachers and their students, especially when teaching Islamic studies, which requires an interest in and inclination towards the subject. Abdel-Fattah (2010) observes that a self-questioning strategy helps students to develop a self-awareness of the learning process; this helps them examine their own understanding, causing them to become aware of what they are learning and the way in which they learn.

Arian's study (2003) supports the idea that self-questioning is a strategy that benefits secondary-school students more than students at any other stage, because it helps them to transfer the impact of learning and develops organisational skills of the learning process. The self-questioning strategy is a modern educational strategy that synergises well with critical thinking, as it requires students to analyse and evaluate information in order to solve problems and make decisions, rather than simply requiring them to narrate the issue at hand.

The development of critical-thinking skills is one of the most important contemporary educational goals; scholars in the field of educational studies believe that one of the primary aims of education is to equip every student with the skills to reach the right decision at the right time. In this regard, Magdy (2003) emphasises the contribution that training students in critical-thinking skills makes to the development of individuals who are capable of taking responsibility and making decisions, as well as expanding their mental processes.

\section{Research Problem}

Despite the importance of academic achievement in Islamic studies and their impact on learners' lives, many studies (Al-Balawi, 2006; Al-Matroudi, 2009; AlMousa, 2001; Al-Qarni, 2013) have indicated that there has been a decline in students' achievements, due to the teaching methods used, as these neglect the learner and disregard the various approaches to thinking, especially critical thinking. As such, it has been noted, students' scientific and practical skills must be developed (Wahed, 2018).

Al-Surour (2005) notes that there is a strong relationship between critical-thinking skills and self-questioning, as critical-thinking skills are based on questioning (i.e., analytical and evaluative questions), leading to knowledge and understanding. Therefore, Abu Jadu and Nofal (2007) stress the idea that developing the habit of questioning is a basic requirement when developing critical-thinking skills. The current study will examine this issue by asking several pertinent research questions. 


\subsection{Research questions}

This study seeks to answer the following main question:

How effective is the self-questioning strategy at developing academic achievement and critical-thinking skills studying the Fiqh curriculum for secondary-school students?

The following sub-questions arise from this main question:

1. How effective is the self-questioning strategy at developing academic achievement studying the Fiqh curriculum for secondary-school students?

2. How effective is the self-questioning strategy at developing criticalthinking skills studying the Fiqh curriculum for secondary-school students?

3. What is the nature of the correlation between critical-thinking skills and academic achievement studying the Fiqh curriculum for secondary-school students?

\subsection{Research hypotheses}

This study seeks to verify the following hypotheses:

1. There is no statistically significant difference at the level $(\alpha \geq 0.05)$ between the average test scores of the experimental group (which was studying using the self-questioning strategy) and the control group (which was studying using the traditional method).

2. There is no statistically significant difference at the level $(\alpha \geq 0.05)$ between the average test scores when testing the critical-thinking skills of the experimental group and the control group.

3. There is no statistically significant correlation at the level $(\alpha<0.05)$ between critical-thinking skills and academic achievement.

\subsection{Research aims}

This study aims to:

1. Determine the effectiveness of the self-questioning strategy at developing academic achievement studying the Fiqh curriculum for secondary-school students.

2. Determine the effectiveness of the self-questioning strategy at developing critical-thinking skills studying the Fiqh curriculum for secondary-school students.

3. Determine the nature of the correlation between critical-thinking skills and academic achievement studying the Fiqh curriculum for secondary-school students.

\subsection{Research importance}

\subsubsection{Theoretical importance}

This is the first study to investigate the effectiveness of the self-questioning strategy studying the Fiqh curriculum in the KSA. It evaluates the use of modern teaching trends, which emphasise the students' role in the educational process and focus on developing students' critical thinking. 


\subsubsection{Practical importance}

This study aims to develop the critical-thinking faculty of students through a selfquestioning strategy. It directs teachers to apply the self-questioning strategy in the teaching of Islamic studies and introduces a guide to the self-questioning strategy that can be applied when teaching the Fiqh curriculum.

\section{Terminology used in this study}

The following terms are used in this study:

- Self-questioning strategy:

In this strategy, the student asks themselves several questions before, during and after a lesson. These questions may help develop academic achievement and critical-thinking skills.

- The Fiqh curriculum:

A KSA curriculum that tackles the purposes of Sharia and offers a set of legal rulings and limits (Ministry of Education, 2018).

- Academic achievement:

Grades that secondary-school students receive following the achievement test prepared for this purpose.

- Critical thinking:

A pattern of thinking that gives a learner the ability to make correct judgments (according to certain criteria) related to the issues, situations and problems they face.

- Critical-thinking skills:

The ability to evaluate the validity and accuracy of information considering the evidence and data available to the learner and to reach correct logical conclusions.

\section{Theoretical literature and related studies}

Over the past century, educators have focused their research efforts on different teaching methods, examining their ability to achieve desirable educational outcomes for learners at different educational stages. On this topic, it has been said that "a successful teacher is nothing but a successful method, and those in charge of teacher training have trained their students to use different teaching methods that help them achieve the goals of teaching easily and successfully" (Bashir, 2017).

\subsection{The self-questioning strategy}

The self-questioning strategy is an important strategy used to develop awareness. As noted, when following this strategy, a student will ask themselves several questions before, during and after a lesson. These questions will facilitate understanding and encourage the student to think about important elements, such as their main ideas, the title of their work, and their previous experience (AlAtoum et al., 2008).

Nassar (2015) also observes that this strategy is one that combines cognitive and metacognitive properties when used in different ways. This is because it helps the student to focus on the details, to summarise their knowledge, and to recognise 
the important elements of their study, as well as increasing an awareness of the knowledge they have gained and the processes that have been performed on it. Self-questioning is known under several different names, including self-planning, self-assessment, and self-reflection (Hamid, 2000), as well as the strategy of selfinterrogation (Attia, 2009).

\subsubsection{The importance of the self-questioning strategy}

The self-questioning strategy is based on the student's positivity as applied to the educational process. This is because the questions that students ask build emotional and cognitive motives; thus, they become more responsible for their own learning. The importance of the self-questioning strategy can be summarised as follows:

1. It helps students to formulate any questions they have about the topic they are studying, allowing them to engage in a dialogue concerning what they know and what they would like to know.

2. It increases students' understanding of the topic at hand, allowing more of their energy to be directed towards teamwork; thus, it makes them more efficient students.

3. Students are made to rely on themselves when constructing meaning; as such, its impact is retained for a long time.

4. Students' questions reveal their thinking style, alternative concepts, their perceptual understanding, and what they want to know.

5. Students become more sensitive to important parts of the lesson content. They evaluate their understanding of the educational material (in the sense that they become aware of what they previously did not understand) and they take remedial action by asking themselves and/or their peers questions or by engaging in additional reading (Ramadan, 2005).

\subsubsection{Self-questioning strategies: steps}

According to Attia (2009), the self-questioning strategy contains the following steps:

The teacher introduces the topic to the students, provided that it is a topic that arouses the students' interest.

1. The students are encouraged to ask themselves questions in order to activate their metacognitive processes before they start the learning process.

2. Students read around the subject carefully, asking themselves questions that aid the planning and organisation of the learning process.

3. Students evaluate the results and take notes on their observations and performance.

4. The teacher investigates and examines the students' responses to selfinterrogation and shows the students how to benefit from them. This is the final stage of the self-questioning process.

4.1.3. The difference between the self-questioning strategy and the "know, want, learn" strategy

Due to the similarity of the steps involved, El-Ghahori (2012) believes that the selfquestioning strategy is the same as the "know, want, learn" (KWL) strategy. However, some scholars - such as Bahloul (2004) - differentiate between the two strategies, but without showing the differences. Having reviewed several studies 
on this topic, the authors of this current paper have determined what these differences are: namely, that metacognitive strategies have three main dimensions: planning, organising and supervising.

We have also found that, while the control aspect is more visible in the selfquestioning strategy, the organising aspect is more visible in the KWL strategy (the two strategies share the planning aspect). As such, we believe that questions asked as part of the self-questioning strategy are more profound, due to the development of the learners' questions.

\subsection{Critical thinking}

Critical thinking is one of the most important topics studied here, because it empowers learners with the basic skills needed as part of the learning and teaching process.

\subsubsection{The definition of critical thinking}

Critical thinking is a careful judgment as to whether we should accept, reject or postpone a decision regarding a particular request or issue. It also assumes that we have a degree of confidence in what we accept or reject (Saadeh, 2011). Udall and Daniels (1991) define critical thinking as the ability to verify and evaluate something based on previously agreed criteria.

Critical thinking is also the ability to evaluate information and examine opinions, taking into account the perspectives on the topic under study (Abu Jad \& Nofal, 2007). Nabhan (2001) states that critical thinking is the apparent behaviour of an individual in a particular situation and regarding a specific subject about which a judgment or practical behaviour is required, considering the data and facts available to the individual. Finally, Qatami (2004) states that critical thinking is reasonable reflective thinking that focuses on what an individual believes or does. In summary, critical thinking can be defined as thinking patterns that give a learner the ability to make correct judgments (according to certain criteria) regarding the issues, situations and problems they face.

\subsubsection{Critical thinking and education}

Education benefits from critical thinking, being an evaluative and judgmental process that moves through a logical thought process to solve problems. Some researchers believe that critical thinking corresponds to the higher levels of Bloom's classification; this approach has been adopted by the KSA Ministry of Education (Faqihi, 2016).

\subsubsection{Critical-thinking skills}

There are many elements to and classifications of critical-thinking skills. This is due to the various different opinions on and definitions of the topic, the most famous of which is Watson and Glaser's classification, which divides criticalthinking skills as follows (Al-Qahtani, 2010):

1. The skill of inference:

This is the ability to distinguish between the degrees of probability concerning how right or wrong a result is, depending on the degree of its connection to certain given facts. 
2. The skill of forecasting assumptions:

This is the ability to examine events or facts; it is judged considering the available data or evidence.

3. The skill of deduction:

This is the learner's ability to derive the relationships between given facts, such that they can judge the extent to which a result derived from said facts is truly connected or not, regardless of the validity of the facts given or the position of the learner.

4. The skill of interpretation:

This is the ability to justify or draw certain conclusions considering facts or witnessed incidents that have been accepted by the human mind.

5. The skill of evaluating discussions:

This is learners' ability to distinguish between strengths and weaknesses when judging an issue or a fact considering the available evidence.

\subsubsection{The relationship between self-questioning and critical thinking}

Abu Jad and Nofal (2007) stress that developing a questioning ability is one of the basic requirements needed for the development of critical thinking. As Al-Surour (2005) observes, there is a strong and stable relationship between critical-thinking skills and self-questioning; this is because critical-thinking skills are based on questioning, which leads to knowledge and understanding through analytical and evaluation questions.

Therefore, we should not hesitate to ask the questions that lead to knowledge of what we must do in matters of religion, worship and dealings with people. At the same time, when asking questions, we should maintain the necessary legal limits and morals.

A student should be aware that knowledge is derived from questions and answers; that a good question is half the way to possessing knowledge and that the ability to ask the right question is one of the most important thinking skills.

\subsection{Academic achievement}

Academic achievement is a basic criterion affecting most decisions related to the student, the curriculum and the educational process. Students' progress in the educational process and their achievement of goals are recognised through academic achievement.

With its various knowledge aspects, academic achievement is one of the factors shaping students' personality; this is why educators are keen for students to obtain the maximum possible amount of knowledge through the learning process.

\subsubsection{The concept of academic achievement}

For the purpose of this study, we define "academic achievement" as marks obtained by secondary-school students in the achievement test prepared for this research. 


\subsubsection{The importance of academic achievement}

Academic achievement is one of the most important goals of education, as it allows an awareness of the level at which students are performing, of teachers' performance, and the appropriateness of the means and curricula used to achieve society's educational goals.

Academic achievement helps students to become aware of their abilities, as well as informing parents of the level of their child's performance. It is one of the criteria that institutions rely on in order to move students from one educational stage or level to another.

Finally, high academic achievement (in comparison to low achievement) inspires confidence in students (Adam, 2015).

\subsubsection{Factors affecting academic achievement}

There are many factors that affect academic achievement, including the mental abilities of the student, their motivation to learn, the educational, economic and social level of the family, and teachers' competence and sincerity.

\subsection{The Fiqh curriculum and secondary-school students' critical thinking}

Critical thinking may help to enlighten students about legal rulings, offering them the ability to elicit, distinguish and direct their questions and to anchor them to reality. As such, we believe that the Fiqh curriculum has a major role to play in developing critical-thinking skills, because it covers important subjects related to students' lives, environments, homeland and nation. It contributes to building a generation whose members are useful to society; this is because it plays a major role in teaching students about legal rulings, linking them to reality and developing students' abilities to solve problems.

Secondary-school students need to acquire the various aspects of thinking skills that will enable them to generate mental evidence or clues, make conclusions, recognise the large number of lessons learned from a religious perspective, and evaluate all these with reference to appropriate criteria (Metwally, 2017).

\subsection{Studies relating to the self-questioning strategy, critical thinking and academic achievement}

4.5.1. Studies on the self-questioning strategy

The self-questioning strategy is relatively recent; it conforms to the requirements of the current era as it helps the learner control their study. Al-Anzi's (2013) study aims to identify the impact of the self-questioning strategy through its development of second-grade intermediate KSA students' metacognitive skills and academic achievement in monotheism (Tawheed). Al-Tarhouni (2012) examines the effect that the self-questioning strategy has on achievement and on the development of critical-thinking skills among students of the Faculty of Arts/Department of Education at Misurata University, while Gamal (2014) evaluates the impact of the self-questioning strategy when teaching the Prophet's biography, analysing its effect on the achievement and critical thinking of firstgrade intermediate students at Al-Azhar in Egypt. 
Fallatah (2015) considers the effectiveness of self-questioning and reciprocal teaching strategies in terms of their ability to improve academic achievement and develop reflective-thinking skills among female students attending the Islamic Education Teaching Methods course at Umm Al-Qura University. Al-Shayji (2018) evaluates how effectively the self-questioning strategy develops the academic achievement and critical-thinking skills of ninth-grade intermediate students in the Islamic Fiqh unit in the State of Kuwait.

Finally, Al-Qahtani (2010) examines the effectiveness of teaching science using the self-questioning strategy in terms of academic achievement and the development of reflective-thinking skills. His study uses the quasi-experimental approach, the results of which show that there are statistically significant differences attributed to the use of the self-questioning strategy (in terms of its effect on students' achievement and the development of reflective-thinking skills) when compared to the usual traditional method. Considering this, Al-Qahtani recommends both using the self-questioning strategy at different educational stages and including certain self-questioning activities in scientific curricula.

\subsubsection{Studies on critical thinking}

Ali (2009) considered the impact of the guided discovery and brainstorming methods in terms of their effect on the development of critical-thinking skills and the academic achievement of secondary-school students in Tabuk under the Fiqh curriculum, while Al-Anzi (2013) demonstrates the effectiveness of using the constructivist learning model to develop critical-thinking skills and academic achievement under this curriculum. Al-Shamlaty (2015) identifies the effect using probing questions has on achievement and on the development of criticalthinking skills when teaching interpretation to second-grade intermediate students. Al-Shammari (2019) examines how a learner autonomy model can be used to develop critical-thinking skills and jurisprudential curiosity under the Fiqh curriculum, considering its effect on third-grade intermediate students in Dammam.

\subsubsection{Studies on academic achievement under the Figh curriculum}

Al-Ghamdi's study (2009) evaluates the impact of the systemic approach when teaching the Fiqh curriculum, looking at its effect on the academic achievement of second-grade intermediate students in the Makkah region. Al-Qarawi (2010), using a quasi-experimental approach, considers the effect that using the multiple intelligence teaching strategy has on the achievement of third-grade intermediate students undertaking a Fiqh course. Al-Khatib (2010) shows the effect of using the V-shaped map on the acquisition of jurisprudential concepts and the formation of an integrated conceptual structure among students at Al-Hussein Bin Talal University in Jordan.

Abu Shareekh (2011) investigates the effect that the multiple intelligence and "six hats" strategies have on the achievement and development of the critical-thinking skills of tenth-grade students, as well as their effect on students' attitudes towards learning Islamic Fiqh. Al Boughbran (2013) examines the effect software has on 
first-year secondary female students' achievements (at Khamis Mushait Educational District, KSA) and their attitudes to this software.

Awajan (2015) considers the effectiveness of teaching according to the theory of multiple intelligence and its effect on academic achievement and the development of creative-thinking skills among fifth-grade primary female pupils studying the Islamic Fiqh unit, comparing this effect to that of the usual teaching strategy. Ali (2016) examines the effect using the cooperative learning strategy has on the achievement of seventh-grade pupils studying for a basic education in Sana'a.

Faqihi (2016) investigates the effectiveness of using concept maps in terms of their ability to improve the achievement and critical thinking of second-year secondary-school students, while Al-Otaibi (2017) considers the use of a visual strategy (based on knowledge-load theory) and its effect on the achievement of second-grade secondary-school students studying the Fiqh curriculum. Finally, Al-Omari (2019) has studied the effectiveness of the inverted class, in terms of academic achievement, focusing on first-year secondary students.

\section{Research procedures}

Our research uses the quasi-experimental approach, which is a scientific method of solving problems that is based on a real test of hypotheses concerning causeand-effect relationships. The experimental method has the highest degree of scientific control.

In this study, we sought to learn and measure the impact of the independent variable, which is the self-questioning strategy, on the two dependent variables (the academic achievement and critical-thinking skills of secondary-school students). Our research design is based on two groups (see Table 1).

Table 1

\begin{tabular}{|c|c|c|c|}
\hline & $\begin{array}{l}\text { The academic } \\
\text { achievement and } \\
\text { critical-thinking } \\
\text { skills tests (before } \\
\text { the experiment) }\end{array}$ & The experiment & $\begin{array}{l}\text { The academic } \\
\text { achievement and } \\
\text { critical-thinking } \\
\text { skills tests (after } \\
\text { the experiment) }\end{array}$ \\
\hline $\begin{array}{l}\text { Experimental } \\
\text { group }\end{array}$ & $\checkmark$ & $\begin{array}{l}\text { Teaching the Prohibited } \\
\text { Sales Unit using the self- } \\
\text { questioning strategy }\end{array}$ & $\checkmark$ \\
\hline $\begin{array}{l}\text { Control } \\
\text { group }\end{array}$ & $\checkmark$ & $\begin{array}{l}\text { Teaching the Prohibited } \\
\text { Sales Unit using the } \\
\text { traditional method }\end{array}$ & $\checkmark$ \\
\hline
\end{tabular}

As seen in Table 1, the design of the research experiment is based on the experimental group that studied using the self-questioning strategy, and the control group that studied in the usual way, and the research applied a test of academic achievement and a test of critical-thinking skills in Fiqh curriculum before and after the experiment on both groups. 


\subsection{The research community}

The current research community consists of all secondary-school students in West Dammam in the Eastern Province of the Kingdom of Saudi Arabia that are enrolled in government schools during the first semester of the academic year 2020/2021 (8179 students).

\subsection{The research sample}

A random sample was selected from the study community, and the researchers followed the following research procedures:

1. An inventory was made of all secondary public education schools in the city of Dammam, based on the official lists of the General Administration of Education in the Eastern Province (52 schools, including 23 schools in East Dammam, and 30 schools in West Dammam).

2. An inventory was made of all regular secondary-school students studying during the first semester of 2020/2021, according to the West Dammam Supervision Office (8179 students).

3. Two secondary schools were randomly selected from the list of schools.

4. Two classes that were studying Fiqh 1 were randomly chosen from the selected schools.

5. The Al-Qasim bin Muhammad school was chosen to represent the control group, while the Abu Sufyan bin Al-Harith school was chosen as the experimental group.

6. Six classes were studying Fiqh in the Al-Qasim bin Muhammad School, two of which were randomly selected to represent the control group, while eight classes were studying Fiqh 1 in the Abu Sufyan bin Al-Harith School, two of which were randomly selected to represent the experimental group.

\subsection{The research variables}

\subsubsection{First (independent) variable}

The independent variable is the self-questioning strategy.

\subsubsection{Second (dependent) variable}

The dependent variable is academic achievement and critical-thinking skills.

\subsubsection{Third (confounding) variables}

\section{- Type:}

The two study groups were selected from male students only, in government schools in Dammam, which are subject to the education system in the Kingdom of Saudi Arabia.

- Chronological age:

The students' ages were determined using the school records; it was found that all the students studying the Fiqh 1 course are between 16-18 years of age and are studying the course for the first time. Therefore, it can be said that the two groups are equivalent in terms of the chronological age variable.

- Study content:

To ensure parity and equality between the two groups, in terms of the academic content under study, all elements of the academic content were taken from the Fiqh 1 book for the secondary stage: Prohibited Sales Unit. 
Table 2 shows the specific topics considered as part of this study.

Table 2

\begin{tabular}{|c|l|c|l|}
\hline $\begin{array}{c}\text { Topic } \\
\text { no. }\end{array}$ & \multicolumn{1}{|c|}{ Subject matter } & $\begin{array}{c}\text { Topic } \\
\text { no. }\end{array}$ & \multicolumn{1}{|c|}{ Subject matter } \\
\hline 1 & Reason for prohibited earning & 6 & Selling the sample \\
\hline 2 & Monopoly & 7 & Sale of Tawaruq \\
\hline 3 & Usury & 8 & Gambling and ambiguous sale \\
\hline 4 & Usury of sales & 9 & Insurance \\
\hline 5 & Exchange contract & & \\
\hline
\end{tabular}

This unit was chosen because of its consistency and the interdependence of its contents, which make the unit suitable for an analysis of the self-questioning strategy and critical-thinking skills.

\subsection{The research instruments}

5.4.1. First instrument: an academic achievement test for secondary-school students

The construction of an achievement test requires the following steps:

1. Determining the objective of the achievement test.

2. Preparing a table for the specifications.

3. Determining the type of test questions to be asked.

4. Formulating and arranging the test questions.

5. Preparing the test instructions.

6. Forming the answer key.

\subsubsection{Second instrument: a test of critical-thinking skills for secondary-school students}

This test aims to determine the level of secondary-school students' criticalthinking skills before they are developed using the self-questioning strategy. The purpose of this test is to establish a valid scale with which to measure the criticalthinking skills of students undertaking the Fiqh 1 Prohibited Sales Unit.

The test consists of 40 questions, which are divided into five skills: inference; deduction; discussion evaluation; knowledge of axioms or assumptions; and interpretation. Each skill consists of 8 questions; the student gets one mark for each correct answer.

Table 3: Correlation coefficients for each statement of the axis statements with the total score of the axis to which it belongs

\begin{tabular}{|c|l|l|l|l|l|}
\hline \multirow{2}{*}{ Serial } & \multicolumn{5}{|c|}{ Correlation coefficient } \\
\cline { 2 - 6 } & Inference & Deduction & $\begin{array}{c}\text { Discussion } \\
\text { evaluation }\end{array}$ & $\begin{array}{c}\text { Knowledge of } \\
\text { axioms or } \\
\text { assumptions }\end{array}$ & Interpretation \\
\hline 1 & $0.505^{* *}$ & $0.736^{* *}$ & $0.803^{* *}$ & $0.492^{* *}$ & $0.465^{* *}$ \\
\hline 2 & $0.804^{* *}$ & $0.736^{* *}$ & $0.859^{* *}$ & $0.591^{* *}$ & $0.757^{* *}$ \\
\hline 3 & $0.449^{* *}$ & $0.515^{* *}$ & $0.491^{* *}$ & $0.730^{* *}$ & $0.662^{* *}$ \\
\hline 4 & $0.769^{* *}$ & $0.763^{* *}$ & $0.701^{* *}$ & $0.494^{* *}$ & $0.409^{* *}$ \\
\hline 5 & $0.429^{* *}$ & $0.658^{* *}$ & $0.635^{* *}$ & $0.671^{* *}$ & $0.784^{* *}$ \\
\hline 6 & $0.498^{* *}$ & $0.691^{* *}$ & $0.536^{* *}$ & $0.494^{* *}$ & $0.4665^{* *}$ \\
\hline 7 & $0.818^{* *}$ & $0.406^{* *}$ & $0.729^{* *}$ & $0.433^{* *}$ & $0.4977^{* *}$ \\
\hline 8 & $0.559^{* *}$ & $0.562^{* *}$ & $0.446^{* *}$ & $0.748^{* *}$ & $0.458^{* *}$ \\
\hline$* *$ significant at 0.01. & \multicolumn{5}{|l}{} \\
\hline
\end{tabular}


The reliability of the instrument was calculated using Cronbach's alpha.

Table 4 shows the value of the reliability coefficient for each axis of the questionnaire.

Table 4: Reliability coefficient

\begin{tabular}{|l|c|}
\hline \multicolumn{1}{|c|}{ Axis } & $\begin{array}{c}\text { Reliability } \\
\text { coefficient }\end{array}$ \\
\hline Inference skill & 0.760 \\
\hline Deduction skill & 0.758 \\
\hline Discussion evaluation skill & 0.807 \\
\hline Knowledge of axioms or assumptions skill & 0.824 \\
\hline Interpretation skill & 0.778 \\
\hline The questionnaire as a whole & 0.917 \\
\hline
\end{tabular}

It is clear from Table 4 that the reliability coefficients are high, indicating that the questionnaire has a high degree of reliability.

\section{Research results}

This study's aim was to learn how effective the self-questioning strategy is at developing the academic achievement and critical-thinking skills of secondaryschool students studying the Fiqh curriculum for secondary-school students. Therefore, a quasi-experimental design was used that tested the control group both before and after the experiment.

The researchers' aim is to present the results of the study and its interpretation, and to discuss the results by answering the research questions and their associated hypotheses.

\subsection{The first hypothesis}

There is no statistically significant difference at the level $(\alpha \geq 0.05)$ between the average test scores of the experimental group (which was studying using the self-questioning strategy) and the control group (which was studying using the traditional method).

To verify the validity of this hypothesis, the researchers used a t-test to show the differences between the two independent groups, so as to identify the significance of the differences between the average scores of the experimental group and the scores of the control group in the post application of the total score of the achievement test (Table 5).

Table 5: T-test for the significance of the differences between the average scores of the experimental group and the scores of the control group in the post-application of the achievement test

\begin{tabular}{|c|c|c|c|c|c|c|c|}
\hline Group & No & $\begin{array}{c}\text { Arithmetic } \\
\text { average }^{*}\end{array}$ & $\begin{array}{c}\text { Standard } \\
\text { deviation }\end{array}$ & $\begin{array}{c}\text { T- } \\
\text { value }\end{array}$ & $\begin{array}{c}\text { Significance } \\
\text { level }\end{array}$ & Comment & $\begin{array}{c}\text { Eta } \\
\text { square }\end{array}$ \\
\cline { 1 - 6 } Experimental & 32 & 63.52 & 19.44 & 2.90 & 0.005 & $\begin{array}{c}\text { Significant } \\
\text { at } 0.01\end{array}$ & 0.12 \\
\hline Control & 32 & 50.23 & 17.09 & & & \\
\hline
\end{tabular}

*The average has been converted to 100 marks. 
Table 5 shows that the value of $\mathrm{T}$ is significant at a level less than 0.05 , which indicates that there are statistically significant differences between the average of the experimental group and the control group in the scores of the post-application of the achievement test. These differences were in the experimental group's favour.

It is also clear from the same table that the effect of ETA square on the total score of the achievement test is 0.12 , which means only $12 \%$ of the total variance of the differences between the average scores of the post-application of the achievement test for the two groups. This is considered an average effect, according to Cohen's criteria (which explains the effect of the independent variable on the dependent variable), because an effect that explains about $1 \%$ of the variance indicates a small effect, about $6 \%$ indicates a medium effect and about $15 \%$ or more indicates a high effect.

The results of this study agree with Omar (2008) and Al Shayji (2018), both of whom examine how effective the self-questioning strategy is at developing students' academic achievement. The results also agree with those of Al-Qarawi (2010), Awajan (2015) and Al-Otaibi (2017), which consider the development of academic achievement under the Fiqh curriculum.

These results can be attributed to the fact that the self-questioning strategy made students feel more positive during the learning process, as they are given the opportunity to test their previous knowledge and link it with their new knowledge, leading to corrected mistakes and questions generated during and after studying, and thus leading to better academic achievement. In addition, selfquestioning provided an effective learning environment that made the student the central focus of the educational process through positive participation.

\subsection{The second hypothesis}

There is no statistically significant difference at the level $(\alpha \geq 0.05)$ between the average test scores when testing the critical-thinking skills of the experimental group and the control group.

To verify the validity of this hypothesis, the researchers used a t-test to show the differences between the two independent groups, so as to identify the significance of the differences between the average scores of the experimental group and the scores of the control group in the post application of the sub-skills and the total score of the critical-thinking test (Table 6).

Table 6: T-test for the significance of differences between the average scores of the experimental group and the scores of the control group in the post application of the critical-thinking test

\begin{tabular}{|c|c|c|c|c|c|c|c|c|}
\hline Skills & Group & No & $\begin{array}{l}\text { Arithmetic } \\
\text { average* }\end{array}$ & $\begin{array}{l}\text { Standard } \\
\text { deviation }\end{array}$ & $\begin{array}{c}T \\
\text { value }\end{array}$ & $\begin{array}{c}\text { Significance } \\
\text { level }\end{array}$ & Comment & $\begin{array}{c}\text { Eta } \\
\text { square }\end{array}$ \\
\hline \multirow{2}{*}{$\begin{array}{l}\text { Inference } \\
\text { skill }\end{array}$} & Experimental & 32 & 71.48 & 19.37 & \multirow{2}{*}{2.74} & \multirow{2}{*}{0.008} & \multirow{2}{*}{$\begin{array}{l}\text { Significant } \\
\text { at } 0.01\end{array}$} & \multirow{2}{*}{0.11} \\
\hline & Control & 32 & 58.20 & 19.47 & & & & \\
\hline \multirow{3}{*}{$\begin{array}{l}\text { Deduction } \\
\text { skill }\end{array}$} & Experimental & 32 & 58.20 & 21.44 & \multirow{2}{*}{1.85} & \multirow{2}{*}{0.069} & & \multirow{2}{*}{0.05} \\
\hline & Control & 32 & 48.44 & 20.76 & & & significance & \\
\hline & Experimental & 32 & 66.41 & 19.43 & 1.40 & 0.166 & & 0.03 \\
\hline
\end{tabular}




\begin{tabular}{|c|c|c|c|c|c|c|c|c|}
\hline $\begin{array}{l}\text { Discussion } \\
\text { evaluation } \\
\text { skill }\end{array}$ & Control & 32 & 59.77 & 18.44 & & & $\begin{array}{c}\text { No } \\
\text { significance }\end{array}$ & \\
\hline \multirow{2}{*}{$\begin{array}{l}\text { Knowledge } \\
\text { of axioms or } \\
\text { assumptions } \\
\text { skill }\end{array}$} & Experimental & 32 & 54.69 & 20.27 & \multirow[b]{2}{*}{2.24} & \multirow[b]{2}{*}{0.029} & \multirow[b]{2}{*}{$\begin{array}{l}\text { Significant } \\
\text { at } 0.05\end{array}$} & \multirow[b]{2}{*}{0.08} \\
\hline & Control & 32 & 42.97 & 21.52 & & & & \\
\hline \multirow{2}{*}{$\begin{array}{l}\text { Interpretation } \\
\text { skill }\end{array}$} & Experimental & 32 & 61.72 & 24.99 & \multirow{2}{*}{0.97} & \multirow{2}{*}{0.338} & \multirow{2}{*}{$\begin{array}{c}\text { No } \\
\text { significance }\end{array}$} & \multirow{2}{*}{0.01} \\
\hline & Control & 32 & 56.25 & 20.08 & & & & \\
\hline \multirow{2}{*}{$\begin{array}{l}\text { Total mark } \\
\text { for the } \\
\text { critical- } \\
\text { thinking test }\end{array}$} & Experimental & 32 & 62.50 & 16.52 & \multirow[b]{2}{*}{2.43} & \multirow[b]{2}{*}{0.018} & \multirow[b]{2}{*}{$\begin{array}{l}\text { Significant } \\
\text { at } 0.05\end{array}$} & \multirow[b]{2}{*}{0.09} \\
\hline & Control & 32 & 53.20 & 14.20 & & & & \\
\hline
\end{tabular}

* The average has been converted to 100 marks.

Table 6 shows that the $T$ values are significant at the level of 0.05 , and less for the skills of inference and knowledge of axioms or assumptions, as well as for the total score for the critical-thinking test. This indicates that there are statistically significant differences between the averages of the experimental group and the control group in the post-application scores for those skills. These differences were in the experimental group's favour.

Table 6 also shows that the values for $\mathrm{T}$ are not significant for the skills of deduction, discussion evaluation and interpretation, indicating that there are no statistically significant differences between the averages of the experimental group and of the control group in terms of the marks given for the post application of those skills in the critical-thinking test.

This table also indicates that the ETA square for the total score of the criticalthinking test is 0.09 , which means that only $9 \%$ of the total variance in the differences between the average marks given for the post-application scores in the critical-thinking test for the two groups is due to the effect of teaching using the self-questioning strategy for the two groups. This is considered an average effect according to Cohen's criteria.

These results agree with those of studies that have examined the effectiveness of the self-questioning strategy at developing critical-thinking skills among students (Al-Shayji, 2018).

The study of the inference and knowledge of axioms or assumptions skills shows a large function in the experimental group's favour. "Inference" means the ability to draw conclusions based on premises, considering a set of facts and knowledge before judging their validity; this result thereby illustrates the interrelationship between the self-questioning strategy and critical-thinking skills. We can attribute this to the fact that the students in the experimental group are practising different mental activities and skills during the educational process, generating ideas and training their inference and assumption abilities. This result agrees with Ramadan (2005) and Al-Shammari (2019).

Accordingly, we reject the second hypothesis. This can be attributed to the use of the self-questioning strategy to developing critical-thinking skills, because learners asks questions and guesses the answer, leading to the stimulation of the 
their critical-thinking ability and helping them to retrieve relevant previous experiences.

\subsection{The third hypothesis}

There is no statistically significant correlation at the level $(\alpha<0.05)$

between critical-thinking skills and academic achievement.

To answer this question, the researchers used the Pearson correlation coefficient to measure the relationship between the scores for the research sample $(n=64)$ in the sub-skills and the total score for the critical-thinking test, and their scores in the achievement test (Table 7).

Table 7: Results for both the experimental and control groups measuring the relationship between the scores for sub-skills and the total score for the critical-thinking skills test and their scores in the achievement test $(n=64)$

\begin{tabular}{|l|l|l|l|}
\hline Skills & \multicolumn{1}{|c|}{$\begin{array}{c}\text { Correlation } \\
\text { coefficient }\end{array}$} & \multicolumn{1}{|c|}{ Significance } & $\begin{array}{l}\text { Description of the } \\
\text { correlation }\end{array}$ \\
\hline Inference skill & 0.4864 & Significant at 0.01 & $\begin{array}{l}\text { Positive } \\
\text { correlation }\end{array}$ \\
\hline Deduction skill & 0.5605 & Significant at 0.01 & $\begin{array}{l}\text { Positive } \\
\text { correlation }\end{array}$ \\
\hline $\begin{array}{l}\text { Discussion evaluation } \\
\text { skill }\end{array}$ & 0.4899 & Significant at 0.01 & $\begin{array}{l}\text { Positive } \\
\text { correlation }\end{array}$ \\
\hline $\begin{array}{l}\text { Knowing axioms or } \\
\text { assumptions skill }\end{array}$ & 0.5344 & Significant at 0.01 & $\begin{array}{l}\text { Positive } \\
\text { correlation }\end{array}$ \\
\hline $\begin{array}{l}\text { Interpretation skill } \\
\text { Total mark for the } \\
\text { critical-thinking test }\end{array}$ & 0.4430 & Significant at 0.01 & $\begin{array}{l}\text { Positive } \\
\text { correlation }\end{array}$ \\
\hline
\end{tabular}

Table 7 shows that there are direct (positive) correlations between the skills covered by the critical-thinking test (inference, deduction, evaluation of discussions, knowledge of axioms or assumptions and interpretation) and the total score for the achievement test. This indicates that, potentially, the higher the marks achieved for the critical-thinking test by the research sample (secondaryschool students), the higher their level of academic achievement under the Fiqh curriculum. These correlations were statistically significant at a 0.01 level.

It is also clear from Table 7 that there is a direct (positive) correlation between the total score for the critical-thinking test and the total score for the achievement test. This indicates that, potentially, the higher the marks achieved for the criticalthinking test by the research sample (secondary-school students), the higher their level of academic achievement under the Fiqh curriculum. These correlations were statistically significant at a 0.01 level. 
Table 8: Results for the experimental group measuring the relationship between the scores for sub-skills and the total score for the critical-thinking skills test and their scores in the achievement test $(n=32)$

\begin{tabular}{|l|l|l|l|}
\hline \multicolumn{1}{|c|}{ Skills } & $\begin{array}{l}\text { Correlation } \\
\text { coefficient }\end{array}$ & Significance & \multicolumn{1}{c|}{$\begin{array}{c}\text { Description of the } \\
\text { correlation }\end{array}$} \\
\hline Inference skill & 0.5452 & Significant at 0.01 & Positive correlation \\
\hline Deduction skill & 0.4631 & Significant at 0.01 & Positive correlation \\
\hline $\begin{array}{l}\text { Discussion } \\
\text { evaluation skill }\end{array}$ & 0.3896 & Significant at 0.01 & Positive correlation \\
\hline $\begin{array}{l}\text { Knowing axioms or } \\
\text { assumptions skill }\end{array}$ & 0.5070 & Significant at 0.01 & Positive correlation \\
\hline $\begin{array}{l}\text { Interpretation skill } \\
\text { Total mark for the } \\
\text { critical-thinking test }\end{array}$ & 0.4832 & Significant at 0.01 & Positive correlation \\
\hline
\end{tabular}

Table 8 shows that there are direct (positive) correlations between the skills covered by the critical-thinking test (inference, deduction, evaluation of discussions, knowledge of axioms or assumptions and interpretation) and the total score for the achievement test. This indicates that, potentially, the higher the marks achieved for the critical-thinking test by the research sample (secondaryschool students), the higher their level of academic achievement under the Fiqh curriculum. These correlations were statistically significant at a 0.05 level or less. It is also clear that there is a direct (positive) correlation between the total score for the critical-thinking test and the total score for the achievement test. This indicates that, potentially, the higher the marks achieved for the critical-thinking test by the research sample, the higher their level of academic achievement. These correlations are statistically significant at a 0.01 level.

Table 9: Results for the control group measuring the relationship between the scores for sub-skills and the total score for the critical-thinking skills test and their scores in the achievement test $(n=32)$

\begin{tabular}{|l|l|l|l|}
\hline Skills & $\begin{array}{l}\text { Correlation } \\
\text { coefficient }\end{array}$ & Significance & $\begin{array}{l}\text { Description } \\
\text { of the } \\
\text { correlation }\end{array}$ \\
\hline Inference skill & 0.2818 & No significance & $\begin{array}{l}\text { Positive } \\
\text { correlation }\end{array}$ \\
\hline Deduction skill & 0.6034 & Significant at 0.01 & $\begin{array}{l}\text { Positive } \\
\text { correlation }\end{array}$ \\
\hline $\begin{array}{l}\text { Discussion } \\
\text { evaluation skill }\end{array}$ & 0.5555 & Significant at 0.01 & $\begin{array}{l}\text { Positive } \\
\text { correlation }\end{array}$ \\
\hline $\begin{array}{l}\text { Knowing axioms } \\
\text { or assumptions } \\
\text { skill }\end{array}$ & 0.4706 & Significant at 0.01 & $\begin{array}{l}\text { Positive } \\
\text { correlation }\end{array}$ \\
\hline Interpretation skill & 0.3569 & Significant at 0.01 & $\begin{array}{l}\text { Positive } \\
\text { correlation }\end{array}$ \\
\hline $\begin{array}{l}\text { Total mark of } \\
\text { critical thinking } \\
\text { test }\end{array}$ & 0.6416 & Significant at 0.01 & $\begin{array}{l}\text { Positive } \\
\text { correlation }\end{array}$ \\
\hline
\end{tabular}


Table 9 shows that there are direct (positive) correlations between the skills covered by the critical-thinking test (inference, deduction, evaluation of discussions, knowledge of axioms or assumptions and interpretation) and the total score for the achievement test. This indicates that, potentially, the higher the marks achieved for the critical-thinking test by the research sample (secondaryschool students), the higher their level of academic achievement under the Fiqh curriculum. These correlations are statistically significant at a 0.05 level or less, except for the inference skill, which has no statistical significance.

It is also clear that there is a direct (positive) correlation between the total score for the critical-thinking test and the total score for the achievement test. This indicates that, potentially, the higher the marks achieved for the critical-thinking test by the research sample, the higher their level of academic achievement. These correlations are statistically significant at a 0.01 level. This result is consistent with Al-Anzi (2013).

The researchers attribute the above results to the fact that the development of critical-thinking skills and academic achievement are highly correlated, that is, developing one side leads to the development of the other. Accordingly, we reject the third hypothesis.

\section{Conclusions}

The study offers useful findings, in that it indicates:

1. How effective the self-questioning strategy is at improving the academic achievement of secondary-school students studying the Fiqh curriculum.

2. How effective the self-questioning strategy is at developing the criticalthinking skills of secondary-school students studying the Fiqh curriculum.

3. There is a correlation between critical-thinking skills and the academic achievement of secondary-school students studying the Fiqh curriculum.

We can explain this by saying that the self-questioning strategy makes students more positive during the learning process. Additionally, students have the opportunity to test their previous knowledge and link it to their new knowledge; this leads to corrected mistakes and to the generation of new questions, leading in turn to better academic achievement and improved critical-thinking skills. The self-questioning strategy also provides an effective learning environment that makes students the focus of the educational process, facilitating the assimilation of information and making students capable of making their own decisions on different aspects of life.

The researchers attribute the third finding to the fact that development of criticalthinking skills and academic achievement is highly correlated, that is, developing one side leads to the development of the other side.

\section{Research recommendations and suggestions}

Considering the research results, we recommend the following:

1. Attention should be given to modern teaching methods (including the strategy of self-questioning) at all academic levels, especially the secondary 
stage. These methods should be included in the curricula of teaching colleges, thereby training student teachers in a manner that can keep up with today's needs.

2. The Ministry of Education, and those in charge of curricula, need to pay attention to means of developing thinking skills. Additionally, they should encourage teachers to use these approaches through continuous training courses, informing them of the most important developments in this field and thereby improving their teaching competencies.

3. Greater awareness among teachers is necessary; this could be achieved through educational bulletins and guided reading concerning the importance of teaching critical thinking to young people.

4. The training of thinking skills needs further attention, both in general education and among Islamic education teachers and supervisors in particular. This can be achieved by organising in-service training courses.

5. The completion of a course related to thinking skills in general and critical thinking in particular should be a professional requirement for teachers.

6. Students should be made the main focus of the educational process. This can be achieved by giving them a primary role in any discussion and analysis and by teaching them to search for questions, derive ideas and use them correctly.

Based on our results, and considering the recommendations, we suggest that the following future avenues of research would be worthwhile:

1. Building a programme based on self-questioning strategies that can develop all types of thinking skills.

2. Conducting research into the effect of self-questioning strategy on the development of jurisprudential skills.

3. Conducting an analytical study of the effect of critical-thinking skills on the curricula overall.

\section{Acknowledgement}

The authors extend their thanks to the participating research sample and everyone who facilitated the research procedures, as this work is part of an unpublished master's thesis under the supervision of the first author in this paper and the hard work of the second author.

\section{References}

Abanmi, F. bin A. (2016). The effect of using the flipped classroom strategy in teaching interpretation on academic achievement and attitude toward the subject, among second year secondary students. Journal of Reading and Knowledge, 172, 21-48.

Abdel Fattah, A. (2010). Teaching and Learning Strategies Models and Applications. University Book House.

Abdel Wahed, A. A. (2018). The effectiveness of teaching critical-thinking skills in the life skills of fourth-grade science students. Journal of Arts, Literature, Humanities and Sociology, 25, 400-415.

Abdul Hamid, A. (2000). The effectiveness of certain cognitive strategies in developing some higher reading comprehension skills among first-year secondary students. Reading and Knowledge Journal, 2, 189-241. 
Abu Ajwa, H. S. (2009). The effect of self-questioning strategy on developing solving chemical problems for eleventh grade students [Unpublished master's thesis]. Gaza Islamic University.

Abu Jad, Saleh \& Nofal, B. (2007). Teaching Thinking: Theory and Practice. Dar Al Masirah for Publishing and Distribution.

Abu Shareekh, S. T. (2011). The effect of using strategies of multiple intelligences and the six hats on the achievement and development of critical-thinking skills among the tenth-grade students in Jordan and their attitudes towards teaching Islamic Fiqh. Education Journal, 145(2), 341-375.

Adam, A. K. (2015). Problems facing secondary school principals and their impact on academic achievement: An application on Khartoum State in the period from (2014-2015) [Unpublished doctoral dissertation]. University of the Holy Quran and Islamic Sciences.

Al Boughbran, M. (2013). The effect of using a computerized educational software on the achievement of first-year secondary-school students in the field of Figh in the schools of Khamis Mushait Educational District in the Kingdom of Saudi Arabia and their attitudes towards it [Unpublished doctoral dissertation]. University of Jordan.

Al-Anzi, F. bin M. (2013). The effectiveness of using the constructivist learning model in developing critical-thinking skills and academic achievement in Figh course for thirdgrade intermediate students [Unpublished doctoral dissertation]. Umm Al Qura University.

Al-Atoum, A. Y. et al. (2008). eilm alnafs altarbawii alnazariat waltatbiq alaistadh alduktur shafiq falah ealawna alaistadh alduktur eadnan yusuf aleatuwm alduktur eabd alnaasir dhiab aljaraah alduktur mueawiat mahmud abu ghazal [Educational Psychology Theory and Application 11 th ed.]. Dar Al Masirah.

Al-Balawi, H. M. (2006). The extent to which the second intermediate-grade students in Jeddah acquire the prescribed Fiqh concepts [Unpublished master's thesis]. College of Education for Girls in Jeddah.

Al-Ghamdi, F. A. (2009). The effect of using the systemic approach in teaching Fiqh on the academic achievement of students in Makkah Al-Mukarramah intermediate schools. Journal of Studies in Curricula and Educational Supervision, 1(1), 162-243.

Ali, A. G. M. G. (2016). The effectiveness of the cooperative learning strategy in teaching Fiqh on the achievement of seventh-grade students of fundamental education. Specialized International Educational Journal, 50(7), 333-353.

Ali, Y. bin A. K. (2009). On the path of guided discovery and brainstorming methods in developing critical-thinking skills and academic achievement in Figh of secondary-school students in the city of Tabuk [Unpublished master's thesis]. Umm Al Qura University.

Al-Khatib, O. S. (2010). The effect of using the V-shape map on the acquisition of jurisprudential concepts and the formation of an integrated conceptual structure among students of Al-Hussein Bin Talal University in Jordan. Journal of the Association of Arab Universities, 55, 197-230.

Al-Matroudi, K. bin I. (2009). The extent to which sixth-grade primary pupils in Riyadh have acquired the prescribed Fiqh concepts. Reading and Knowledge Journal, 98, 129-169.

Al-Mofda, S.S. (2005). The effect of applying cooperative learning on the achievement of second-grade secondary students of Fiqh (experimental study). Reading and Knowledge Journal, 48, 94-144.

Al-Mousa, Y. M. F. (2001). The Degree of Acquisition of Basic Concepts Contained in Islamic Figh in the Sharia Schools Affiliated with the Palestinian Ministry of Awqaf and Religious Affairs by Students of the Seventh, Eighth and Ninth Grades [Master's thesis, An-Najah National University]. 
Al-Otaibi, H. (2017). The effectiveness of the formality strategy based on the cognitive burden on the achievement of secondary school female students in the subject of Fiqh. Journal of Scientific Research in Education, 18(2), 425-443.

Al-Qahtani, N. bint S. (2010). Critical-thinking skills of female students at the College of Education at the universities of King Saud University and the Emirate University. A comparative study. Journal of the Modern Education Association, 3(7), 329-406.

Al-Qarawi, A. R. bin A. (2010). The effect of using the multiple intelligences strategy on the achievement of the third intermediate grade students in Figh course [Unpublished master's thesis]. Imam Muhammad Bin Saud Islamic University.

Al-Qarni, A. bin M. (2013). The effect of using mental maps in teaching the developed course of Figh on the achievement of first-grade intermediate students in Jeddah [Unpublished master's thesis]. Umm Al Qura University.

Al-Shamlaty, O. A.-Q. (2015). The effect of teaching interpretation using probing questions on the achievement and development of critical-thinking skills among secondgrade intermediate students. Journal of Human and Administrative Sciences, 7, 6496.

Al-Shammari, T. (2019). The effectiveness of the learner independence model in developing critical-thinking skills and jurisprudential curiosity in Figh curriculum for third-grade intermediate students [Unpublished master's thesis]. Imam Abdul Rahman AlFaisal University.

Al-Shayji, S. (2018). The impact of self-questioning strategy on developing academic achievement and developing critical thinking among middle ninth-grade students in the Islamic Fiqh unit in the State of Kuwait. Educational Journal, 127(32), 51-88.

Al-Surour, N. (2005). Teaching Thinking in the School Curriculum. Dar Wael for Publishing and Distribution.

Al-Tarhouni, A. A. R. (2012). The effect of using self-questioning strategy on the achievement and development of some critical-thinking skills among students of the Department of Education, Faculty of Arts, Misurata University [Unpublished master's thesis]. University of Misurata.

Arian, S. (2003). The effectiveness of the metacognition strategy in the achievement of philosophy among first-year secondary students and its impact on their attitudes towards reflective philosophical thinking. Journal of Reading and Knowledge, 20, 113-139.

Attia, M. A. (2009) Metacognitive Strategies in Understanding Reading. Dar Al-Manahg for Publishing and Distribution.

Awajan, W. S. M. (2015). The effectiveness of strategies based on multiple intelligences in developing academic achievement and creative thinking skills among female students of Islamic Fiqh in the fifth-grade primary. Journal of Educational and Psychological Sciences, 16(1), 197-236.

Bahloul, I. A. (2004). Recent trends in metacognitive strategies in teaching reading. Journal of Reading and Knowledge, 30, 148-280.

Bashir, M. T. (2017). Effective teaching strategies and ways of thinking. Researches of the First International Conference: Reading the Arab and Islamic Heritage Between the Past and the Present, 5, 459-472.

Education Document (1970). Education Policy in the Kingdom of Saudi Arabia, amended in 1995.

El-Ghahori, N. A. (2012). The effectiveness of self-scheduling strategy (K.W.L.H.) in developing deep understanding of physical concepts and metacognition skills for eighth-grade students in the Sultanate of Oman. Arab Studies in Education and Psychology, 1(32), 11-58.

http://ijlter.org/index.php/ijlter 
Fallatah, R. (2015). The effectiveness of self-questioning strategy and reciprocal teaching in developing academic achievement and reflective thinking among female students of the Islamic Education Teaching Methods course at Umm Al-Qura University [Unpublished doctoral dissertation]. Umm Al-Qura University.

Faqihi, F. M. A. (2016). The effectiveness of using concept maps in developing achievement and critical thinking among female students of the second-year secondary in the subject of Fiqh [Unpublished master's thesis]. King Khalid University.

Gamal, T. (2014). The effect of using self-questioning strategy in teaching the biography of the Prophet on the achievement and critical thinking of Al-Azhar first-year preparatory students. Education Journal, 158(3), 327-369.

Magdy, H. A. K. (2003). Teaching Thinking: Future Strategies for the New Millennium. Dar Al Fiker Alarabi.

Metwally, E-S. S. E.-S. (2017). A proposed strategy based on active learning for teaching Fiqh in developing some critical-thinking skills among Al-Azhar secondaryschool students. Arab Studies in Education and Psychology, 86, 151-181.

Ministry of Education (2018). Secondary Education Guide: Curricula System. Secondary Education Development Project.

Nabhan, S. (2001). A proposed program for developing critical thinking in mathematics among ninth grade students in Gaza [Unpublished doctoral dissertation]. Ain Shams University.

Nassar, A. A. H. (2015). The effect of using thinking maps strategy on developing critical-thinking skills and science processes for tenth-grade students [Unpublished master's thesis]. Islamic University, Gaza.

Omar, S. M. (2008). The effectiveness of using students' self-questioning in developing cognitive achievement and self-efficacy among students studying philosophy at the secondary stage. Journal of the Educational Society for Social Studies, 17, 15.

Qatami, N. (2004). Effective Teaching Skills. Dar Al-Fikr.

Ramadan, H. A. M. (2005). The interaction between some metacognitive strategies and information processing levels in developing scientific concepts and critical thinking for first-year middle-school students in science. Journal of Scientific Education, 8(1), 181-236.

Saadeh, J. A. (2011). maharat altafkir (mae 1997, altatbiqiatu) jawdat 'ahmad saeada [Teaching Thinking Skills.] Dar Al-Shorouk for Publishing and Distribution.

Udall, A. J, \& Daniels, J. E. (1991). Creating the Thoughtful Classroom: Strategies to Promote Student Thinking. Zephyr Press. 